\title{
Cyclic AMP in sheep ovarian follicles: site of production and response to gonadotrophins
}

\author{
T. J. Weiss, R. F. Seamark, J. E. A. McIntosh*† and R. M. Moor $\uparrow$ \\ Department of Obstetrics and Gynaecology, University of Adelaide, \\ Adelaide, South Australia 5000, and \\ $\dagger$ Agricultural Research Council Unit of Reproductive Physiology and Biochemistry, \\ University of Cambridge, 307 Huntingdon Road, Cambridge CB3 0JQ, U.K.
}

\begin{abstract}
Summary. This study was undertaken (i) to establish a relationship between cyclic AMP (cAMP) production and the degree of LH and FSH stimulation; (ii) to determine the effects of various gonadotrophins on follicular formation of cAMP; and (iii) to identify the precise intrafollicular site of cAMP formation.

The formation of cAMP increased rapidly in follicles exposed to LH. Maximum concentrations were reached after $90 \mathrm{~min}$ and were maintained for $180 \mathrm{~min}$. Extracellular release of cAMP increased steadily throughout the 180 -min experimental period. Tissue levels of cAMP increased proportionally and significantly when LH concentrations in the medium were increased from 0 to $200 \mathrm{mi}$.u. $\mathrm{ml}^{-1}$.

Tissue levels of cAMP were significantly increased by HCG, prostaglandin E-2 and noradrenaline, but not by prolactin, prostaglandin F-2 $\alpha$, serotonin or melatonin.

Cyclic AMP formation occurred predominantly in the thecal compartment; the membrana granulosa contributed less than $3 \%$ of the total amount of cAMP formed after gonadotrophic stimulation. A significant amount of cAMP from the thecal cells was released into the extracellular compartment and appeared to pass into the granulosa cells.
\end{abstract}

\section{Introduction}

Some of the earliest changes in ovarian tissue after stimulation by gonadotrophins are of the tissue content and release of cyclic AMP (cAMP). There is now compelling experimental support for the proposal that the stimulation of ovarian steroidogenesis by LH and FSH is mediated by cAMP (Lindner et al., 1974). This nucleotide, or its dibutyryl derivative, has been shown to mimic the steroidogenic action of gonadotrophins on isolated luteal and follicular tissue.

As part of a study on the action of gonadotrophins on the ovarian follicles of sheep, the role of cAMP has been investigated.

\section{Materials and Methods}

Ovaries were removed from sheep of mixed breed (mainly Merino crossbreds) within 40 min of slaughter and transported to the laboratory in ice-chilled Dulbecco phosphate-buffered saline (Commonwealth Serum Laboratories, Parkville, Victoria, Australia) containing $50 \mu \mathrm{g}$ Kanamycin $\mathrm{ml}^{-1}$ (Sigma Chemical Company, St Louis, Missouri, U.S.A.). Follicles between 4 and $6 \mathrm{~mm}$ in diameter were dissected from the ovaries of sheep between Days 4 and 14 of the cycle, and were established individually in organ culture as described by Moor (1973). The incubation volume depended on the height of the grid and the size of the follicle and was approximately $1 \mathrm{ml}$. Steroido5000 .

* Present address: Department of Obstetrics and Gynaecology, University of Adelaide, Adelaide, South Australia 
genic function of the isolated follicles was assessed after $24 \mathrm{hr}$ by analysis of the culture medium for immunoreactive oestrogen (Moor, Hay, McIntosh \& Caldwell, 1973). After the initial $24 \mathrm{hr}$ culture period the follicles were randomly allocated to one of three experiments.

Experiment 1. This experiment was to relate the amount of cAMP formed and released into the medium to the degree of gonadotrophin stimulation. The culture medium was replaced $24 \mathrm{hr}$ after explantation with fresh medium or incubation buffer containing LH (NIH-LH-S18; 1.03 i.u. $\mathrm{mg}^{-1}$ ) or FSH (NIH-FSH-S10; $1 \cdot 10$ i.u. $\mathrm{mg}^{-1}$ ). The serum levels for the ewe range from 0.4 to $1200 \mathrm{ng} \mathrm{ml}^{-1}$ for LH, 120-500 ng ml-1 for FSH and 20-340 $\mathrm{ng} \mathrm{ml}^{-1}$ for prolactin (Akbar, Nett \& Niswender, 1974). In Exp. 1(a) the concentration of gonadotrophin was kept constant at 50 mi.u. $\mathrm{ml}^{-1}$ medium, but the length of exposure of follicles to the gonadotrophin was varied from 0 to 180 min. In Exp. 1(b) the length of exposure to $\mathbf{L H}$ and FSH was kept constant at 40 min but the concentration of gonadotrophin was varied from 0 to 200 mi.u. $\mathrm{ml}^{-1}$ medium. After culture, the follicle was transferred to an all-glass homogenizer containing the incubation buffer-1 $\mathrm{ml} 50 \mathrm{~mm}$-tris-HCl buffer, pH 7•4, 8 mM-theophylline (Calbiochem, California, U.S.A.) and 6 mM-2-mercaptoethanol (Koch Light Labs Ltd, Buckinghamshire, U.K.). After homogenization the extract was centrifuged $(800 \mathrm{~g}, 10 \mathrm{~min})$ to remove cell debris and the supernatant and culture medium were assayed separately for cAMP.

Experiment 2. The effect of HCG (Pregnyl: Organon, Morden, Surrey, U.K.), prolactin (NIHP-S11; 26.4 i.u. $\mathrm{mg}^{-1}$ ), prostaglandins (PG) E-2 (U-12062: Upjohn Pty. Ltd, Parramatta, N.S.W., Australia) and F-2 $\alpha$ (tromethamine salt; U-14583: Upjohn), noradrenaline (DL-arterenol hydrochloride: Sigma), serotonin (Sigma) and melatonin (Sigma) on the formation of cAMP in intact follicles was assessed. The follicles were exposed to the appropriate hormone for $40 \mathrm{~min}$; the method of treatment and the final termination and homogenization of tissue was as described for Exp. 1 .

Experiment 3. Identification of the precise cellular component responsible for the production of cAMP in gonadotrophin-treated follicles was attempted. One group of follicles was exposed for 40 min to culture medium containing HCG. Each follicle was then placed in $1 \mathrm{ml}$ incubation buffer and a small incision made in the follicle wall. The granulosa cells were washed from the thecal casing using an angled Pasteur pipette with the tip drawn to a $0.5 \mathrm{~mm}$ point. The washing process was repeated 15 times to ensure nearly complete removal of granulosa cells. The thecal casing was transferred to a second vessel containing $1 \mathrm{ml}$ buffer. The separated tissues were homogenized directly in the buffer and after centrifugation the supernatant was assayed for cAMP.

Follicles in two other groups were placed in incubation buffer or fresh culture medium containing 8 mM-theophylline and separated into the thecal and granulosa components. Gonadotrophin or PG was then added to the vessels containing the isolated tissue components and incubated for $40 \mathrm{~min}$.

\section{Determination of $c A M P$}

Cyclic AMP was determined by saturation analysis using a binding protein contained in the supernatant from an homogenate of sheep adrenals. This extract was prepared by the method of Brown et al. (1971) which was originally developed for extracting the binding protein from cattle adrenals. The sheep adrenal extracts gave excellent results over the range $0-6$ pmol when used at final dilutions of $1: 120$. Each assay tube contained $50 \mu 1$ of a solution of $\left[{ }^{3} \mathrm{H}\right]$ adenosine-(G) $3^{\prime}: 5^{\prime}-$ cyclic phosphate ammonium salt $\left(\left[{ }^{3} \mathrm{H}\right] \mathrm{cAMP}\right.$; sp. act. $22 \cdot 1 \mathrm{Ci} \mathrm{mmol}^{-1}$; New England Nuclear, Boston, Massachusetts, U.S.A.) containing approximately $5000 \mathrm{ct} \min ^{-1}(0.31 \mathrm{pmol})$ cAMP, $100 \mu \mathrm{l}$ binding protein solution and either a known amount of cAMP standard (0-10 pmol: Sigma) or an appropriate portion of tissue extract made up to $200 \mu \mathrm{l}$ with buffer to give a final incubation volume of $350 \mu \mathrm{l}$.

After incubation at $4^{\circ} \mathrm{C}$ for at least $2 \mathrm{hr}, 200 \mu \mathrm{l}$ aliquots of the incubation mixtures were transferred to small columns $(1 \times 3.5 \mathrm{~cm})$ containing $0.5 \mathrm{~g}$ Sephadex G-25 (fine), equilibrated with buffer, to separate free and bound fractions. Elution was with buffer containing theophylline. The void volume $(0.5 \mathrm{ml})$ was discarded and then the protein fraction eluted with $1 \mathrm{ml}$ buffer collected directly into scintillation vials. Scintillator fluid $(10 \mathrm{ml}$ Triton X-100:toluene-PPO-POPOP scintillator, $1: 2(\mathrm{v} / \mathrm{v}))$ was added and the radioactivity determined. In all assays two unequal portions of extracts 
were measured to confirm that parallelism existed between the standard curve and the curve relating to the values obtained. The recovery obtained was $80 \%$.

Testing with a wide range of nucleotides showed that the specificity of the sheep adrenal binding protein was very similar to that described for cattle adrenal tissue (Brown et al., 1971).

The intra- and inter-assay coefficients of variation were $12 \%(n=36)$ and $14 \%(n=10)$, respectively. The minimum amount of cAMP that could be detected was $0.4 \mathrm{pmol} \mathrm{ml}^{-1}$.

Appropriate allowances were made for dilution and the results were expressed in pmol cAMP (mg follicular tissue) $)^{-1}$. Wet weights of follicular tissue were determined from mean follicular diameters using the relationship:

$$
Y=0.523\left(D^{3}-(D-0 \cdot 209)^{3}\right)
$$

where $\mathrm{D}=$ diameter of the follicle in $\mathrm{mm}$ and $\mathrm{Y}=$ wet weight of tissue in $\mathrm{mg}$. The weights of separated theca and granulosa tissue were determined from the relationship:

$$
\mathrm{T}=\mathrm{Y}(\mathrm{G} / 1 \cdot 8)
$$

where $\mathbf{T}$ and $\mathrm{G}$ are the weights in $\mathrm{mg}$ of theca interna and membrana granulosa, respectively.

These relationships were determined by weighing follicular tissue after removing the follicular fluid from 95 follicles, and by calculations based on direct measurements of the thicknesses of the theca interna and granulosa cell layers, assuming a tissue density of 1 . The mean $( \pm$ S.E.M.) thicknesses of the theca interna and membrana granulosa measured in 65 follicles ( 5 measurements per follicle), were $55 \pm 3.5 \mu \mathrm{m}$ and $110 \pm 2.5 \mu \mathrm{m}$ respectively. These measurements indicated a total mean follicular wall thickness of $165 \pm 4 \cdot 3 \mu \mathrm{m}$ whereas the mean figure derived from calculations based on the weight regression was $209 \pm 5 \cdot 0 \mu \mathrm{m}$. However, in the direct measurements of tissue thickness, no allowance was made for shrinkage and in the direct measurements of tissue weight it proved impossible to remove all follicular fluid without loss of granulosa cells.

\section{Results}

\section{Basal cAMP levels}

The mean ( \pm S.E.M.) tissue content of cAMP in 18 unstimulated follicles determined after 18-24 $\mathrm{hr}$ in culture was $1.1 \pm 0.06 \mathrm{pmol} \mathrm{mg}^{-1}$ and the content in the medium was equivalent to a release of $0.35 \pm 0.05 \mathrm{pmol} \mathrm{mg}^{-1}$ tissue. No relationship was apparent between the level of released cAMP and the production of oestrogen by individual follicles.

\section{Experiment 1}

After the addition of gonadotrophin there was a rapid rise in tissue cAMP and a subsequent increase in the levels of cAMP in the medium (Table 1). Addition of LH caused a significant $(\boldsymbol{P}<0.05)$ increase in cAMP concentrations in the tissue within $5 \mathrm{~min}$. Maximum levels were reached at about $90 \mathrm{~min}$ and were maintained for up to $180 \mathrm{~min}$. The concentration of cAMP in the medium was significantly different $(P<0.05)$ from the control value at $15 \mathrm{~min}$ and continued to increase throughout the period of observation.

A similar pattern of cAMP production was seen following treatment with FSH (Table 1), but the amounts formed were less than those observed after the addition of LH.

When the concentrations of FSH or LH were increased (Table 2), there was an increase in cAMP production up to about $40 \mathrm{mi}$.u. $\mathrm{ml}^{-1}$ medium. No further cAMP production occurred with addition of hormone at concentrations up to $100 \mathrm{mi}$.u. $\mathrm{ml}^{-1}$, but $200 \mathrm{mi}$.u. $\mathrm{ml}^{-1}$ caused a marked rise $(P<0.01)$ in the tissue content of cAMP. The plateau in the dose-response and time course of both LH and FSH was an inexplicable but repeatable phenomenon. 
Table 1. Effect of varying the length of exposure to LH ( $\left.50 \mathrm{mi} . \mathrm{u} . \mathrm{ml}^{-1}\right)$ or FSH ( $\left.50 \mathrm{mi} . \mathrm{u} . \mathrm{ml}^{-1}\right)$ on the formation and release of cyclic AMP (pmol $\mathrm{mg}^{-1}$, mean \pm S.E.M.) by sheep ovarian follicles maintained in organ culture

\begin{tabular}{|c|c|c|c|c|c|c|}
\hline \multirow{2}{*}{$\begin{array}{l}\text { Period of } \\
\text { exposure } \\
\text { (min) }\end{array}$} & \multicolumn{3}{|c|}{$\mathbf{L H}$} & \multicolumn{3}{|c|}{ FSH } \\
\hline & No. of follicles & Tissue cAMP & cAMP in medium & No. of follicles & Tissue cAMP & cAMP in medium \\
\hline $\mathbf{0}$ & 15 & $1 \cdot 2 \pm 0.2$ & $0.4 \pm 0.05$ & & & \\
\hline 5 & 5 & $2.4 \pm 0.9$ & $0.5 \pm 0.1$ & 4 & $1.4 \pm 0.2$ & $0.2 \pm 0.1$ \\
\hline 15 & 4 & $6.8 \pm 0.6$ & $1.1 \pm 0.2$ & 3 & $3.8 \pm 1.6$ & $1 \cdot 2 \pm 0.4$ \\
\hline 40 & 8 & $44.0 \pm 6.9$ & $7 \cdot 5 \pm 1 \cdot 6$ & 8 & $24 \cdot 2 \pm 5 \cdot 2$ & $5 \cdot 5 \pm 0.6$ \\
\hline 60 & 6 & $44 \cdot 5 \pm 10 \cdot 8$ & $18.3 \pm 4.9$ & 4 & $19 \cdot 7 \pm 2 \cdot 1$ & $5 \cdot 2 \pm 0.9$ \\
\hline 90 & 7 & $75 \cdot 5 \pm 14 \cdot 0$ & $24 \cdot 0 \pm 4 \cdot 8$ & 6 & $56 \cdot 8 \pm 10 \cdot 0$ & $11.9 \pm 1.6$ \\
\hline 120 & 4 & $81 \cdot 4 \pm 19 \cdot 0$ & $47 \cdot 8 \pm 12 \cdot 3$ & & & \\
\hline 180 & 4 & $157 \cdot 0 \pm 19 \cdot 0$ & $103 \cdot 0 \pm 7 \cdot 0$ & & & \\
\hline
\end{tabular}

Table 2. Cyclic AMP (mean \pm S.E.M.) formed and released $\left(\mathrm{pmol} \mathrm{mg}^{-1}\right)$ by sheep ovarian follicles in organ culture after exposure to different concentrations of $\mathrm{LH}$ or FSH for $40 \mathrm{~min}$

\begin{tabular}{|c|c|c|c|c|c|c|}
\hline \multirow{2}{*}{$\begin{array}{l}\text { Gonadotrophin } \\
\text { conc. } \\
\text { (mi.u. } \text { ml }^{-1} \\
\text { medium) }\end{array}$} & \multicolumn{3}{|c|}{$\mathbf{L H}$} & \multicolumn{3}{|c|}{ FSH } \\
\hline & $\begin{array}{l}\text { No. of } \\
\text { follicles }\end{array}$ & $\begin{array}{l}\text { Tissue } \\
\text { cAMP }\end{array}$ & $\begin{array}{l}\text { cAMP in } \\
\text { medium }\end{array}$ & $\begin{array}{l}\text { No. of } \\
\text { follicles }\end{array}$ & $\begin{array}{l}\text { Tissue } \\
\text { cAMP }\end{array}$ & $\begin{array}{l}\text { CAMP in } \\
\text { medium }\end{array}$ \\
\hline 0 & 15 & $1 \cdot 2 \pm 0.2$ & $0.4 \pm 0.05$ & & & \\
\hline 2 & 3 & $18.4 \pm 3.6$ & $3.9 \pm 0.8$ & 3 & $4.2 \pm 0.3$ & $0.6 \pm 0.05$ \\
\hline 20 & 4 & $38.5 \pm 6.2$ & $9.4 \pm 0.8$ & 4 & $11.6 \pm 1.5$ & $1 \cdot 2 \pm 0.01$ \\
\hline 50 & 8 & $44 \cdot 0 \pm 6.9$ & $7 \cdot 5 \pm 1 \cdot 6$ & 8 & $24 \cdot 2 \pm 5 \cdot 2$ & $5.5 \pm 0.6$ \\
\hline 100 & 5 & $46.0 \pm 5.0$ & $4.4 \pm 1 \cdot 8$ & 9 & $16 \cdot 3 \pm 1 \cdot 7$ & $3.4 \pm 0.4$ \\
\hline 200 & 5 & $83 \cdot 3 \pm 10 \cdot 1$ & $11 \cdot 0 \pm 2 \cdot 0$ & 4 & $70 \cdot 3 \pm 15 \cdot 2$ & $8.8 \pm 1.0$ \\
\hline
\end{tabular}

\section{Experiment 2}

The addition of HCG, PGE-2 and noradrenaline caused increases in the tissue content of cAMP, whereas prolactin, PGF-2 $\alpha$, serotonin and melatonin were without effect (Table 3).

Table 3. Formation of cAMP (mean \pm S.E.M.) by sheep ovarian follicles in culture for $40 \mathrm{~min}$ in response to hormones added to the medium

\begin{tabular}{lccc}
\hline \multicolumn{1}{c}{ Hormone } & $\begin{array}{c}\text { Dose } \\
\left(\mathrm{ml}^{-1} \text { medium) }\right.\end{array}$ & $\begin{array}{c}\text { No. of } \\
\text { follicles }\end{array}$ & $\begin{array}{c}\text { cAMP } \\
\left(\text { pmol mg }^{-1}\right)\end{array}$ \\
\hline None (control) & - & 15 & $1.6 \pm 0.4$ \\
HCG & $20 \mathrm{i.u}$. & 4 & $* 50 \cdot 0 \pm 8.8$ \\
Prolactin & $50 \mu \mathrm{g}$ & 6 & $3.2 \pm 0.7$ \\
Prostaglandin E-2 & $20 \mu \mathrm{g}$ & 4 & $* 7 \cdot 3 \pm 0.5$ \\
Prostaglandin F-2 $\alpha$ & $10 \mu \mathrm{g}$ & 10 & $0.7 \pm 0.3$ \\
Noradrenaline & $20 \mu \mathrm{g}$ & 6 & $* 7 \cdot 0 \pm 1 \cdot 2$ \\
Serotonin & $20 \mu \mathrm{g}$ & 6 & $2 \cdot 0 \pm 0.25$ \\
Melatonin & $20 \mu \mathrm{g}$ & 6 & $1.5 \pm 0.3$ \\
\hline
\end{tabular}

* Significantly different from control values, $P<0.02$, by Student's $t$ test.

\section{Experiment 3}

No differences were found between cAMP formation in culture medium and in incubation buffer. Irrespective of whether the thecal and granulosa cells were exposed to HCG before or after separation, the total amount of cAMP formed in the isolated tissues was always similar to that produced by the intact follicle (Table 4). When the theca and granulosa layers were separated after the intact follicle had been incubated with HCG for 40 min about $50 \%$ of the cAMP was associated with each cellular component. 
Table 4. Effect of theophylline on the level of cAMP in entire follicles of sheep and in the separated thecal and granulosa cell components after 40 min exposure to 20 i.u. $\mathrm{HCG} \mathrm{ml}^{-1}$ medium

\begin{tabular}{|c|c|c|c|}
\hline \multirow[b]{2}{*}{ Tissue component } & \multicolumn{2}{|c|}{ Mean $\left( \pm\right.$ S.E.M.) amount of cAMP $\left(\mathrm{pmol} \mathrm{m}^{-1}\right)$} & \multirow[b]{2}{*}{ Significance* } \\
\hline & tTheophylline & -Theophylline & \\
\hline Entire follicle & $0.3 \pm 0.1$ & $1.1 \pm 0.6(18)$ & N.S. \\
\hline Theca & $5 \cdot 4 \pm 1 \cdot 1$ & $4.8 \pm 0.2$ & N.S. \\
\hline Granulosa & $1.2 \pm 0.2$ & $1.5 \pm 0.6 \quad(26)$ & N.S. \\
\hline Medium & $1.05 \pm 0.1$ & $0.2 \pm 0.03$ & $P<0.02$ \\
\hline Entire follicle + HCG & $47 \cdot 0 \pm 4.5(4)$ & $51 \cdot 9 \pm 12 \cdot 0 \quad(16)$ & N.S. \\
\hline \multicolumn{4}{|l|}{$H C G$ before separation } \\
\hline Theca & - & $39.4 \pm 8.0 \quad(7)$ & - \\
\hline Granulosa & - & $34 \cdot 3 \pm 7 \cdot 1$ & - \\
\hline Medium & $2.8 \pm 0.6$ & $0.2 \pm 0.02$ & $P<0.02$ \\
\hline \multicolumn{4}{|l|}{$H C G$ after separation } \\
\hline Theca & $49 \cdot 2 \pm 7 \cdot 1(10)$ & $2 \cdot 7 \pm 0.8$ & $P<0.01$ \\
\hline Granulosa & $3.3 \pm 0.4(10)$ & $0.2 \pm 0.05$ & $P<0.05$ \\
\hline
\end{tabular}

The number of follicles in each group is shown in parentheses.

* Calculated for effect of treatment with theophylline using Student's $t$ test.

A different pattern of cAMP distribution was observed when the tissue components were first separated and then treated individually with HCG (Table 4). Almost all cAMP formation was associated with the thecal component; less than $3 \%$ of the total cAMP production occurred in the isolated membrana granulosa. Similar differences in the amount of cAMP formed by thecal and granulosa cells were found when the tissues were exposed to other gonadotrophins and PGE-2 after separation (Table 5).

Table 5. The site of formation of cAMP in sheep follicles (numbers in parentheses)

\begin{tabular}{|c|c|c|}
\hline \multirow[b]{2}{*}{ Hormone } & \multicolumn{2}{|c|}{ cAMP (mean \pm S.E.M.; pmol mg ${ }^{-1}$ ) } \\
\hline & Thecal cells & Granulosa cells \\
\hline None & $2.5 \pm 0.35$ & $1.6 \pm 0.57$ \\
\hline FSH (50 mi.u. $\mathrm{ml}^{-1}$ ) & $14 \cdot 2 \pm 2 \cdot 4$ & $0.37 \pm 0.18$ \\
\hline LH (50 mi.u. $\mathrm{ml}^{-1}$ ) & $43 \cdot 2 \pm 5 \cdot 8$ & $2.97 \pm 0.63$ \\
\hline HCG (20 iu. $\left.\mathrm{ml}^{-1}\right)$ & $49 \cdot 2 \pm 7 \cdot 1 \quad(10)$ & $3.3 \pm 0.4$ (10) \\
\hline PGE-2 $\left(20 \mu \mathrm{g} \mathrm{ml}^{-1}\right)$ & $27 \cdot 8 \pm 10 \cdot 7$ & $0.98 \pm 0.16$ (4) \\
\hline
\end{tabular}

\section{Discussion}

These results show that there is a rapid increase in the synthesis of cAMP by follicles after LH stimulation, and that this response is confined almost exclusively to the thecal cells. More recent observations (T. J. Weiss, unpublished observations) indicate that the amount of cyclic AMP found in the granulosa cells is proportional both to the total amount of nucleotide formed and the time interval between gonadotrophin treatment and the separation of the theca and granulosa elements. The localization of the site of production of CAMP in the thecal component fits well with evidence from autoradiographic studies which shows that receptor sites for $\mathrm{LH}$ in sheep follicles are situated predominantly in the thecal cells (R. M. Moor, unpublished observations), and that LH and HCG are bound primarily in the theca interna in rats (Zeleznik, Midgley \& Reichert, 1974). The number of LH receptors in the granulosa cells of rat follicles increase sharply during luteinization, but no accompanying increase in adenyl cyclase activity occurs in the granulosa cells (K. Ahrén, personal 
communication). Luteinization appears to alter the nature and response of the granulosa cells to $\mathrm{LH}$ and it is probably misleading to apply results of $\mathrm{LH}$ receptor activity obtained in monolayer cultures of granulosa cells to the intact follicle.

Several interesting possibilities are raised by the observation that cAMP appears to be formed in the thecal cells, released into the extracellular compartment and finally transmitted to the membrana granulosa. The role of cAMP in the ovary has been interpreted almost exclusively in terms of its role as an intracellular mediator of protein hormone action. Release of the nucleotide into the extracellular compartment has, however, been observed in a wide variety of tissues including erythrocytes (Davoren \& Sutherland, 1963), rat liver (Broadus et al., 1970), adrenal (Carchman, Jaanus \& Rubin, 1971; Peytremann, Nicholson, Hardman \& Liddle, 1973), testis (Dufau, Watanabe \& Catt, 1973) and prepubertal rat ovaries stimulated with gonadotrophin or PGE-2 (K. Ahrén, personal communication). Our present results suggest that cAMP might in certain circumstances act widely as a diffusion activator (Huxley, 1935).

If cAMP does act as a diffusion activator it must be transmitted from the thecal layer across the basement membrane and finally into the granulosa cells. However, cAMP produced by prepubertal rat ovaries in vitro is degraded rapidly by a membrane-bound phosphodiesterase (G. Selstam, S. Rosberg \& K. Ahrén, personal communication). That this diesterase is present in the sheep follicle was demonstrated by the protective effect of adding theophylline, an inhibitor of the enzyme, to the incubation medium. However, only cAMP released into the medium appeared to be degraded. Some form of protection or specific canalization may explain the apparent ability of the nucleotide to pass intact into the membrana granulosa. The extensively developed complex of gap junctions found between follicular cells of many animals including ewes (Hay \& Moor, 1975) might provide one such means of rapid intracellular communication. These junctions are highly differentiated areas of the plasma membrane which allow a relatively unimpeded transcellular flow of ions and other small molecules (Bennett, 1973). The available evidence indicates that substances with molecular dimensions comparable to that of cAMP can pass readily through gap junctions (Sheridan, 1971).

The observed effects of FSH and prolactin on cAMP formation could be accounted for by LH contamination of the preparations used. However, it has been shown that FSH, freed of contamination with $\mathrm{LH}$, can itself stimulate cAMP formation in follicles obtained from PMSG-treated immature rats (Koch et al., 1973; Nilsson, Rosberg \& Ahrén, 1974).

The stimulatory effect of noradrenaline on cAMP formation indicates that the potential involvement of the catecholamines in ovarian function warrants further detailed investigation, since an influence of monoamines on ovarian vascular control and on the process of ovulation has been suggested (O'Shea \& Phillips, 1974).

The gonadotrophins were the gift of the N.I.H., Bethesda, Maryland, U.S.A. and the prostaglandins were donated by Dr Irvine of Upjohn Pty. Ltd.

\section{References}

Akbar, A.M., NetT, T.M. \& Niswender, G.D. (1974) Metabolic clearance and secretion rates of gonadotropins at different stages of the estrous cycle in ewes. Endocrinology 94, 1318-1324.

BenNeTt, M.V.L. (1973) Function of electrotonic junctions in embryonic and adult tissues. Fedn Proc. Fedn Am. Socs exp. Biol. 32, 65-75.

Broadus, A.E., Kaminsky, N.I., NorthcutT, R.C., Hardman, J.G., Sutherland, E.W. \& Liddle, G.W. (1970) Effects of glucagon on adenosine 3',5'monophosphate and guanosine $3^{\prime}, 5^{\prime}$-monophosphate in human plasma and urine.J. clin. Invest. 49, 22372245.
Brown, B.L., Albano, J.D.M., Ekins, R.P., Sgherzi, A.M. \& TAmpion, W. (1971) Simple and sensitive saturation assay method for the measurement of $3^{\prime}, 5^{\prime}$-cyclic adenosine monophosphate. Biochem. $J$. 121, 561-562.

CARChMan, R.A., JaANus, S.D. \& Rubin, R.P. (1971) The role of adrenocorticotrophin and calcium in adenosine cyclic $3^{\prime}, 5^{\prime}$-phosphate production and steroid release from the isolated, perfused cat adrenal gland. Molec. Pharmacol. 7, 491-499.

Davoren, P.R. \& Sutherland, E.W. (1963) The effect of L-epinephrine and other agents on the synthesis and release of adenosine $3^{\prime}, 5^{\prime}$-phosphate by whole pigeon erythrocytes. J. biol. Chem. 238, 3009-3015. 
Dufau, M.L., Watanabe, K. \& CatT, K.J. (1973) Stimulation of cyclic AMP production by the rat testis during incubation with hCG in vitro. Endocrinology 92, 6-11.

HAY, M.F. \& MOOR, R.M. (1975) Functional and structural relationships in the Graafian follicle population of the sheep ovary. J. Reprod. Fert. 45, 583-593.

HuXLEY, J.S. (1935) Chemical regulation and the hormone concept. Biol. Rev. 10, 427-441.

Koch, Y., Zor, U., Pomerantz, S., Chobsieng, P. \& LINDNER, H.R. (1973) Intrinsic stimulatory action of ovine FSH on rat ovarian adenylate cyclase. $J$. Endocr. 58, 677-678.

Lindner, H.R., Tsafriri, A., Lieberman, M.E., Zor, U., Koch, Y., Bauminger, S. \& BARneA, A. (1974) Gonadotrophin action on cultured Graafian follicles: induction of maturation division of the mammalian oocyte and differentiation of the luteal cell. Recent Prog. Horm. Res. 30, 79-138.

Moor, R.M. (1973) Oestrogen production by individual follicles explanted from ovaries of sheep. J. Reprod. Fert. 32, 545-548.
Moor, R.M., Hay, M.F., McIntosh, J.E.A. \& CAldWELL, B.V. (1973) Effect of gonadotrophins on the production of steroids by sheep ovarian follicies cultured in vitro. J. Endocr. 58, 599-611.

Nilsson, L., Rosberg, S. \& Ahrén, K. (1974) Characteristics of the cyclic 3',5'-AMP formation in isolated ovarian follicles from PMSG-treated immature rats after stimulation in vitro with gonadotrophins and prostaglandins. Acta endocr., Copenh. 77, 559-574.

O'SheA, J.D. \& Phillips, R.E. (1974) Contractility in vitro of ovarian follicles from sheep and the effects of drugs. Biol. Reprod. 10, 370-379.

Peytremann, A., Nicholson, W.E., Hardman, J.G. \& LiDDLE, G.W. (1973) Effect of adrenocorticotropic hormone on extracellular adenosine $3^{\prime}, 5^{\prime}$-monophosphate in the hypophysectomized rat. Endocrinology 92, 1502-1506.

SHERIDAN, J.D. (1971) Dye movement and low resistance junctions between reaggregation embryonic cells. Devl Biol. 26, 627-636.

ZelezNIK, A.J., Midgley, A.R. \& ReicherT, L.E. (1974) Granulosa cell maturation in the rat: increased binding of human chorionic gonadotropin following treatment with follicle stimulating hormone in vivo. Endocrinology 95, 818-825.

Received 4 July 1975 